\title{
DIVERSITY OF THE WEEVIL SUPERFAMILY (COLEOPTERA: CURCULIONOIDEA) IN NORTH ISLAND PASTORAL SYSTEMS: A BRIEF SURVEY
}

\author{
S.D.J. BROWN ${ }^{1}$ and P.J. GERARD ${ }^{2}$ \\ ${ }^{1} 2241$ River Rd, R. D. 1, Hamilton, New Zealand \\ ${ }^{2}$ AgResearch, Ruakura Research Centre, Private Bag 3123, Hamilton, New Zealand
}

Corresponding author: pip.gerard@agresearch.co.nz

Over a four month period between November 2005 and February 2006, pastures in Waikato, Hawke's Bay and Manawatu were sampled at intervals for Curculionoidea as part of the pre-release site assessments for the clover root weevil (Sitona lepidus Gyllenhal) biocontrol programme. Twenty-three species from three families were collected, seven of which were indigenous. The four species collected in the greatest numbers were S. lepidus, Listronotus bonariensis (Kuschel) (Argentine stem weevil), Irenimus compressus (Broun) and Rhinoncus australis Oke. Of these four, only I. compressus is indigenous to New Zealand. Unexpected finds included the collection of single specimens of Microcryptorhynchus sp. and an unidentified Irenimus species. The high numbers of $I$. compressus differ from previous reports contending that I. aequalis (Broun) is the dominant indigenous weevil in North Island pastures. The low percentage of indigenous weevil species collected from the pastures indicates that there are barriers to the colonisation of highly-modified grassland habitats in areas originally covered by forest.

\section{SPRAYVIEW - SOFTWARE TOOLS FOR IMPROVING AGRICHEMICAL USE IN HORTICULTURE}

\author{
S.J. GURNSEY ${ }^{1}$, J.T.S. WALKER ${ }^{1}$ and A.J. HODSON ${ }^{2}$ \\ ${ }^{1}$ HortResearch, Private Bag 1401, Havelock North, New Zealand \\ ${ }^{2}$ HortPlus, 1091 Riverslea Road South, RD2, Hastings, New Zealand \\ Corresponding author: sgurnsey@hortresearch.co.nz
}

HortResearch and HortPlus ${ }^{\mathrm{TM}}$ have developed a suite of software applications for recording, reporting and tracing agrichemical use. They are designed to help industries monitor and self-regulate agrichemical use. The SprayView system contains three different agrichemical software tools. SprayLog is a tool for growers to record agrichemical applications. It can be used on a wide range of permanent and annual crops. Records from SprayLog can be directly uploaded to a central industry spray diary database. SprayView Data Entry is used to enter paper-based spray diary records into a central database. The difference from SprayLog is that it can accept diaries from a number of different properties and locations. SprayView Analyst is used to rapidly analyse agrichemical use patterns and industry key performance indicators once spray diary information has been collated into a central database. Over the last ten years HortResearch and HortPlus ${ }^{\mathrm{TM}}$ have worked with several New Zealand horticultural industry sectors using this software system. Identification of optimum agrichemical use profiles has enabled these industries to dramatically improve their use of agrichemicals. Key issues have included integrated pest management, resistance management and industry benchmarking. These industries now have a solid platform established for responsible agrichemical use in future years. 